\title{
Isolation and Identification of Soil Bacteria Collected from Dibru-Saikhowa, the National Park and Biosphere Reserve Forest of Assam, India
}

\author{
Sudakshina Das ${ }^{1}$, Pradyut Saikia ${ }^{2}$, Partha Protim Baruah $^{3}$, Anuja Chakraborty ${ }^{3}$ \\ ${ }^{1}$ Associate Professor, Department of Zoology, D.H.S.K College, KC Gogoi Path Dibrugarh 786001, Assam, India \\ ${ }^{2}$ J.R.F, Institutional Level Biotech Hub, D.H.S.K College, KC Gogoi Path Dibrugarh 786001, Assam, India \\ ${ }^{3}$ Student, Department of Zoology, D.H.S.K College, KC Gogoi Path Dibrugarh 786001, Assam, India
}

\begin{abstract}
The present study deals with isolation and identification of bacteria from soil collected from different sites of DibruSaikhowa National Park and Biosphere Reserve Forest of Assam, India. Eight strains were isolated from three different sites namely Guijan Ghat, Guijan Gaon and Lekai Gaon of Dibru-Saikhowa, Assam, India. The isolates identified were Staphylococcus aureus, Escherichia coli, Pseudomonas aeruginosa, Shigella spp., Staphylococcus epidermidis, Klebsiella pneumonia, Proteus vulgaris and Enterococcus faecalis on the basis of their morphological study and biochemical tests. Our present study concludes that those microbes present in the soil help in degradation of bio-molecules of dead plants and animals body, controls nutrient energy cycle and thus remain engaged in bioremediation and maintains the ecological balance.
\end{abstract}

Keywords: Bacteria, Soil, Dibru-Saikhowa National Park and Biosphere Reserve Forest.

\section{Introduction}

Dibru-Saikhowa is a National park situated in both Tinisukia and Dibrugarh districts of Asssam and one of the biosphere reserves of India. Dibru-Saikhowa biosphere reserve covers an area of $765 \mathrm{~km}^{2}$ (square kilometer) with a core area of 340 $\mathrm{km}^{2}$ (square kilometer).It lies between $27^{\circ} 30^{\prime} \mathrm{N}$ to $27^{\circ} 45^{\prime} \mathrm{N}$ latitude and $95^{\circ} 10^{\prime} \mathrm{E}$ to $95^{\circ} 45^{\prime} \mathrm{E}$ longitude at an average altitude of $118 \mathrm{~m}$ (range $110-126 \mathrm{~m}$ ), situated at the flood plains of the river Brahmaputra and Dibru along with tributaries namely Lohit, Dibang and Dangori [1]. DibruSaikhowa consists of tropical, hot and humid climate with evergreen and semi-evergreen forests. Several researchers studied and provided fruitful databases on Dibru-Saikhowa National park. However, there is a gap remain in research and development on the study of Arthropoda, Mollusca, Annelida, and microbial diversity, with many other unexplored groups [2]. Dibru-saikhowa biosphere is an important area for the study of microbial diversity and an undisturbed land. Therefore, the study was carried out on isolation and identification of bacteria from Dibru-Saikhowa soil samples.

Microbial biodiversity plays an important role in the maintenance of ecosystem. Microorganism are frequently present in soil, manure and decaying plant tissues which are able to degrade wastes that are correlated with the substrate organic matter [3]. Soil microorganisms are the major organisms responsible for controlling the amount of nutrient cycling and for controlling the amount of nutrient available to plants [4]-[6]. The great strength of soil comes from the life that exists within soil biodiversity ranging from genes and species to communities. A handful of garden soil may contain thousands of species, millions of individuals and many fungal networks. Scientists estimate that at least about one-quarter of species on planet Earth live in soils [7]. This diversity of soil microbes performs a variety of functions in eco-system. It processes waste organic matter to sustain life above the ground; it regulates the carbon flux and the water cycle; it keeps pests at bay and decontaminates polluted land; and it provides raw materials for new pharmaceuticals to tackle infectious diseases [7]. Our study deals with the isolation and identification of bacteria present in soil which gives wide range of microbes that balance the ecosystem of Dibru-Saikhowa.

\section{Materials and Methods}

\subsection{Collection of Soil Samples}

Soil sample were collected from three different sites of Dibru-Saikhowa region. The names of those sites were Guijan Ghat, Lakai Gaon and Guijan Gaon. Soil samples were taken with the help of sterile spatula, in sterile plastic container with cap and were safely brought to the laboratory.

\subsection{Isolation of Microorganism}

Soil collected from three sites was diluted by serial dilution technique. In this technique sample was prepared by adding $1 \mathrm{~g}$ of soil in $9 \mathrm{ml}$ distilled water i.e. $10^{-1}$ to $10^{-4}$ dilution factor. After serial dilution Nutrient Agar media (NAM) plate was prepared for the culture of microorganisms. Under aseptic condition $0.1 \mathrm{ml}$ of soil sample from each sites were spread on the agar plate by glass spreader and incubated at $37^{\circ} \mathrm{C}$ for 24 hours. Mixed culture was obtained on the plates after 24 hours. Pure culture was obtained by streaking technique after incubation at $37^{\circ} \mathrm{C}$ for 24 hours by picking single colony from different mixed culture plates. Colony forming units were determined after 2 days of incubation at $37^{\circ} \mathrm{C}$. The shape and colors of the colonies were examined under the microscope after Gram staining. 


\section{International Journal of Science and Research (IJSR) \\ ISSN (Online): 2319-7064}

Index Copernicus Value (2013): 6.14 | Impact Factor (2014): 5.611

\subsection{Identification and characterization of bacteria}

Selective / Differential media were used such as MacConkey agar medium, Eosine Methylene Blue agar medium, and Mannitol salt agar medium to differentiate and identify bacterial Isolates. Selective / Differential media plates were incubated at $37^{\circ} \mathrm{C}$ for 24 hours from the pure culture plates that was grown on nutrient agar medium. The isolates were then biochemically analyzed for the activities of Catalase, MR-VP test, Starch hydrolysis, Phenylalanine Agar test, Tryptone test, Nitrate test, Indole production and Citrate utilization [8]-[10]. The tests were used to identify the isolates according to Bergey's Manual of Systematic Bacteriology [11].

\section{Result and Discussions}

\subsection{Morphological Characterization}

Eight no. of strains were isolated from the soil samples collected from three different sites of Dibru-Saikhowa region. Identification and characterization of isolated bacteria were performed on the basis of microscopic morphological study such as shape, arrangement, colonies etc. and biochemical tests such as indole production test, methyl red and Voges-proskauer test, citrate utilization test, catalase test, MacConkey test growth at $37^{\circ} \mathrm{C}$. Selective and differentiate media were prepared and the isolated bacteria were inoculated under sterilized conditions incubated at $37^{\circ} \mathrm{C}$ for 24 hours and the results were recorded following the handbook of Bergey's Manual of Systematic Bacteriology. The isolates identified were Staphylococcus aureus, Escherichia coli, Pseudomonas aeruginosa, Shigella spp., Staphylococcus epidermidis, Klebsiella pneumonia, Proteus vulgaris and Enterococcus faecalis

\subsection{Figures and Tables}

In Figure 1; $S$ aureus was identified on Mannitol Salt Agar Medium due to presence of yellow color caused by change of $\mathrm{pH}$ of phenol red by fermentating Mannitol Sugar where as $S$ epidermidis was identified as it does not fermented mannitol and pink color remains.

In Figure 2; $P$ vulgaris was identified on Phenyl Alanine Agar Medium due to the presence of green color on addition of ferric chloride produced on phenylalanine medium.

In Figure 3; Pseudomonas aeruginasa was identified on Simmon Citrate Agar due to utilization of citrate as a carbon source, the enzyme citrase hydrolyzes citrate into oxaoloacetic acid and acetic acid. The oxaloacetic acid is then hydrolyzed into pyruvic acid and $\mathrm{CO}_{2}$. If $\mathrm{CO}_{2}$ is produced, it reacts with components of the medium to produce an alkaline compound (e.g. $\mathrm{Na}_{2} \mathrm{CO}_{3}$ ). The alkaline $\mathrm{pH}$ turns the $\mathrm{pH}$ indicator (bromthymol blue) from green to blue.

In Figure 4; Klebsiella pneumoniae was identified on MacConkey agar medium due to the presence of bright red color caused by the fermentation of lactose.

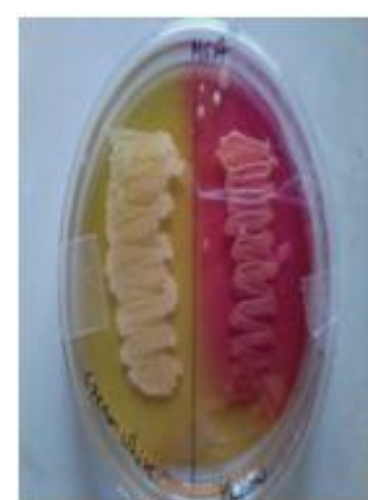

Figure 1

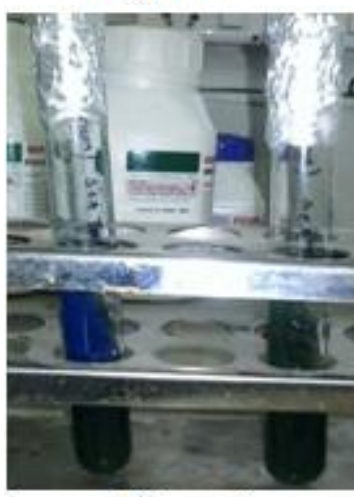

Figure 3

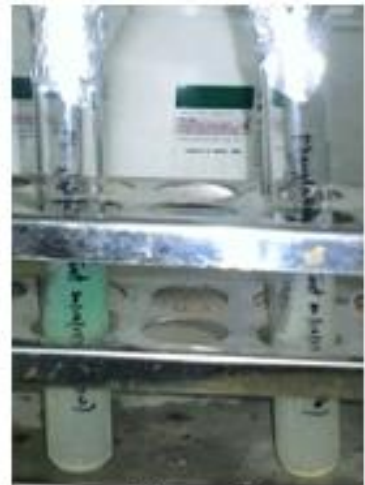

Figure 2

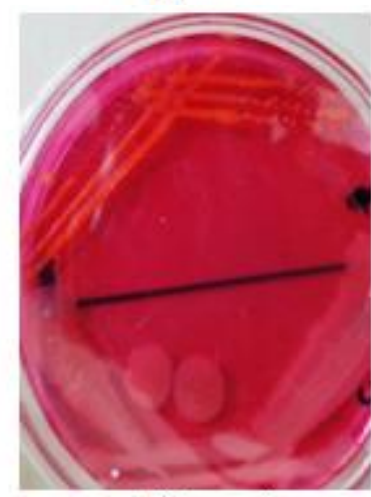

Figure 4
Table 1: Morphological Study of the soil bacteria found

\begin{tabular}{|c|c|c|c|}
\hline Isolates & Site Name & \multicolumn{2}{|c|}{ Colony Color } \\
\hline Isolate1 & Muijan Ghat \& Guijan Gaon & White & Bacilli \\
\hline Isolate2 & Guijan Ghat \& Guijan Gaon & Green & Bacilli \\
\hline Isolate3 & Guijan Ghat \& Lekai Gaon & Cloudy & Bacilli \\
\hline Isolate4 & Guijan Ghat \& Guijan Gaon & Orange & Rods \\
\hline Isolate5 & Guijan Ghat \& Guijan Gaon & Yellow & Cocci \\
\hline Isolate6 & Guijan Ghat \& Guijan Gaon & White & Cocci \\
\hline Isolate7 & Guijan Ghat \& Guijan Gaon & Cream & Cocci \\
\hline Isolate8 & Guijan Ghat \& Lekai Gaon & Orange & Rods \\
\hline
\end{tabular}

Table2 (a): Biochemical Characterization of Isolates:

\begin{tabular}{|c|c|c|c|c|}
\hline Tests & Isolate 1 & \begin{tabular}{|l|} 
Isolate 2 \\
\end{tabular} & Isolate 3 & Isolate 4 \\
\hline Gram Stain & -ve & -ve & -ve & -ve \\
\hline Indole & -ve & -ve & $+\mathrm{ve}$ & $+\mathrm{ve}$ \\
\hline MR & -ve & -ve & +ve & +ve \\
\hline $\mathrm{VP}$ & $+\mathrm{ve}$ & -ve & -ve & -ve \\
\hline MSA & -ve & -ve & -ve & -ve \\
\hline EMB & + ve & -ve & $+\mathrm{ve}$ & -ve \\
\hline Catalase & $+\mathrm{ve}$ & $+\mathrm{ve}$ & $+\mathrm{ve}$ & $+\mathrm{ve}$ \\
\hline Starch & -ve & -ve & -ve & -ve \\
\hline Citrate & + ve & $+\mathrm{ve}$ & -ve & $+\mathrm{ve}$ \\
\hline PA Agar & $-\mathrm{ve}$ & -ve & -ve & $+\mathrm{ve}$ \\
\hline MacConkey & $+\mathrm{ve}$ & -ve & $+\mathrm{ve}$ & -ve \\
\hline $\begin{array}{c}\text { Identified } \\
\text { Bacteria }\end{array}$ & $\begin{array}{c}K \\
\text { pneumoniae. }\end{array}$ & $P$ aeruginasa. & E coli. & $\begin{array}{c}P \\
\text { vulgaris. }\end{array}$ \\
\hline
\end{tabular}




\section{International Journal of Science and Research (IJSR) ISSN (Online): 2319-7064}

Index Copernicus Value (2013): 6.14 | Impact Factor (2014): 5.611

Table2 (b): Biochemical Characterization of Isolates:

\begin{tabular}{|c|c|c|c|c|}
\hline Tests & Isolate 5 & Isolate 6 & Isolate 7 & Isolate 8 \\
\hline Gram Stain & $+\mathrm{ve}$ & $+\mathrm{ve}$ & $+\mathrm{ve}$ & -ve \\
\hline Indole & -ve & -ve & -ve & -ve \\
\hline MR & $-\mathrm{ve}$ & $-\mathrm{ve}$ & $-\mathrm{ve}$ & + ve \\
\hline VP & -ve & $+\mathrm{ve}$ & -ve & -ve \\
\hline MSA & -ve & -ve & $+\mathrm{ve}$ & -ve \\
\hline EMB & -ve & $+\mathrm{ve}$ & -ve & -ve \\
\hline Catalase & $+\mathrm{ve}$ & $-\mathrm{ve}$ & $+\mathrm{ve}$ & $+\mathrm{ve}$ \\
\hline Starch & -ve & -ve & -ve & -ve \\
\hline Citrate & -ve & $+\mathrm{ve}$ & -ve & -ve \\
\hline PA Agar & -ve & -ve & -ve & -ve \\
\hline McConkey & -ve & $+\mathrm{ve}$ & -ve & -ve \\
\hline $\begin{array}{c}\text { Identified } \\
\text { Bacteria }\end{array}$ & $\begin{array}{c}S \\
\text { epidermidis. }\end{array}$ & E faecalis & $S$ aureus. & Shigella sp. \\
\hline
\end{tabular}

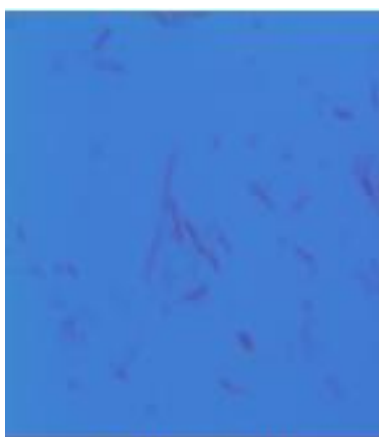

Figure 5 (i)

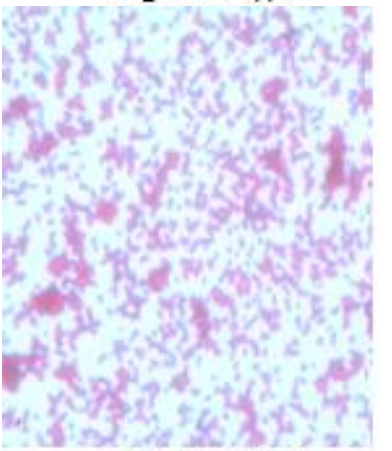

Figure 5 (iii)

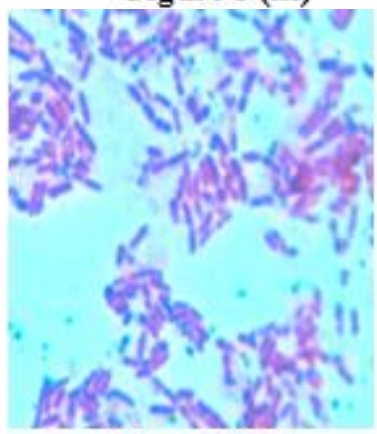

Figure 5 (v)

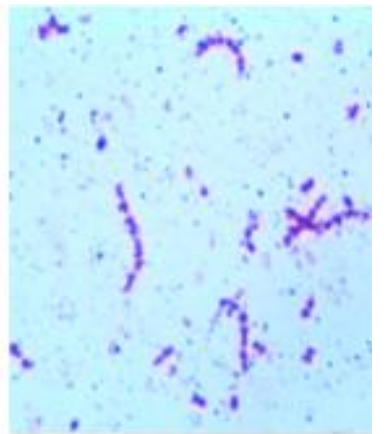

Figure 5 (ii)

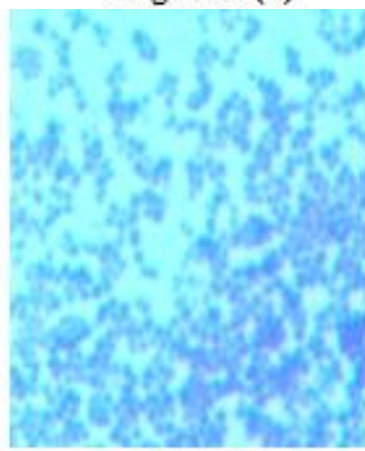

Figure 5 (iv)

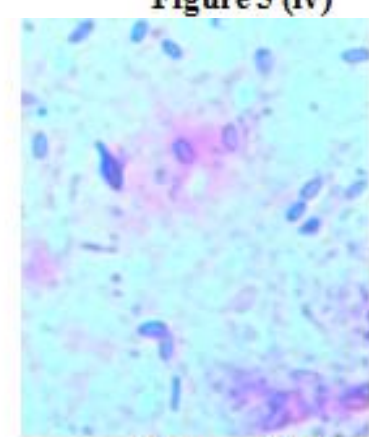

Figure 5 (vi)
Figure 5: Microscopic view of (i) E. coli, (ii) Enterococcus faecalis (iii) Pseudomonas aeruginasa (iv) Staphylococcus epidermidis (v) Shigella spp. and (vi) Klebsiella pneumoniae.by gram staining techniques.

\section{Summary and Conclusions}

Eight strains were isolated from three selected sites of DibruSaikhowa region and were identified by biochemical tests, gram staining following the hand book of Bergey's Manual of Systematic Bacteriology.
The present study reveals that those bacteria present in the soil of Dibru-Saikhowa plays an important role in decomposing the dead materials which is directly responsible for the supply and storage of nutrients in soil which play a role in nutrient cycle. Rates of decomposition differ according to the type of microorganisms present in soil, the character of the organic matters, the physical and chemical environment of the soil and so forth. Nitrogen fixation is an essential function of microbes in forests, hence NPK level remains very high. Many million tons of nitrogen are converted annually and added to the soil by these organisms. Our study also concludes that the microbes present in soil help in bioremediation. Bioremediation is a process through which the microbes in the soil are able to decompose the organic pollutants and convert them into non-toxic molecules. It is the cheapest method of soil decontamination and has proved effective in numerous cases. One famous example was the clean-up of the Exxon Valdez oil tanker spill in Alaska in 1989. As part of efforts to clean crude oil from $2000 \mathrm{~km}$ of coastline, a mix of nutrients and fertilizers which encouraged bacterial growth was applied to the contaminated sand and sediment. The bacterial activity led to a five-fold increase in the rate of oil degradation, and an efficient site clean-up, although the oil spill caused death to many marine and shoreline animals [7]. In a recent published work entitled "Isolation and Identification of heavy metal (lead, zinc and copper) resistant bacteria from oil field soil collected from Moran, Dibrugarh district, Assam", it has been found that heavy metal resistant bacteria such as Klebsellia sp., Staphylococcus sp. and Bacillus sp had been isolated from oil field soil collected from the site nearer to Dibru-Saikhowa shows that the said bacteria have the potentiality to reduce the heavy metals like $\mathrm{Zn}, \mathrm{Cu}$ and $\mathrm{Pb}$ [12]. The present study proves that these bacteria are also found in Dibru-Saikhowa N.P. and Biosphere Reserve. So it can be assumed that these bacteria help in bioremediation, soil detoxification, enhance soil fertility and quality. Healthy fertile soil is the base of bountiful store house of plant, animal and microbial diversity of this Biosphere Reserve. Thus, the soil bacteria of Dibru-Saikhowa not only help in the maintenance of Biodiversity but also maintain ecological balance of this Biosphere Reserve.

\section{Acknowledgement}

We are thankful to D.B.T, Govt. of India for providing financial aid to establish Institutional Level Biotech Hub of D.H.S.K College where the experiments were conducted. We are also thankful to Mr. Tikendrajit Gogoi, Associate Professor, Department of Zoology, D.H.S.K College, Dibrugarh, Assam who lead the study tour to DibruSaikihowa.

\section{References}

[1] K.K. Dwivedi, Incredible Dibru-Saikhowa, DibruSaikhowa Conservation Society, Pragati Offset pvt. Ltd., Hyderabad,

[2] L. M. Singh Palni, and R.S. Rawal, Compendium on Indian Biosphere Reserves. Progression During two Decades of Conservation. 2012. 


\section{International Journal of Science and Research (IJSR) \\ ISSN (Online): 2319-7064}

Index Copernicus Value (2013): 6.14 | Impact Factor (2014): 5.611

[3] M. Alexander, "Introduction to Soil Microbiology," John Wiley \& Sons (2nd Edition), New York, pp. 423437, 1977.

[4] J. Hernot, and G. Robertson, "Vegetation removal in two soils of the humid tropics; Effect on microbial biomass." Soil Biol. Biochem., 15, pp. 93-99, 1994.

[5] S. K. Singh, and J. P. N. Rai, "Soil microbial population and enzyme activity related to grazing pressure in Alpine meadows of Nanda Devi Biosphere Reserve," Journal of Environmental Biology, 25 (1), pp. 103 -107, 2004.

[6] R. K. Jain, M. Kapur, S. Labana, B. Lal, P. M. Sarma, D. Bhattacharya, and I. S. Thakur, "Microbial diversity: Application of micro-organisms for the degradation of xenobiotics," Current Science, 89 (1), pp. 101-112, 2005.

[7] European Commission. The factory of life. Why soil biodiversity is so important. Luxembourg: Office for Official Publications of the European Communities, ISBN 978-92-79-14998-6. 2010.

[8] C.H. Collins, P.M. Lyne, and G.M. Grange, "Collins and Lyne Microbiolo-gical methods," (6th Edition), Butterworth, London, 1989.

[9] J.B. Harold, "Microbiological Applications," Laboratory Manuals in General Microbiology (8th Edition), McGraw - Hill Higher Education, 2002.

[10] H.K. Zaved, M. Rahman Mizanur, M. Rahman Mashir, A. Rahman, S.M.Y. Arafat, and M.S. Rahman, "Isolation and characterization of effective bacteria for solid waste degradation for organic manure KMITL," Sci. Tech. J. 8, pp. 44-55, 2008.

[11]D. Claus, and R.C.W Berkeley, Genus Pseudomonas. In: Bergey's Manual of Systematic Bacteriology (Vol 1, Ed.): Sneath, P.H.A., Mair, N.S. and Sharpe, M.E., pp. 140-219, Baltimore, Williams and wilkins, 1986.

[12] P. Saikia, S. Das, R.K. Shah \& S. Islam, "Isolation and Identification of heavy metal (lead, zinc and copper) resistant bacteria from oil field soil collected from Moran, Dibrugarh district, Assam," International Journal of Advanced Biological Research, 5 (2), pp.150-154, 2015.

\section{Author Profile}

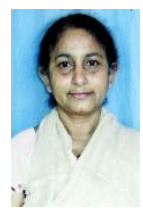

Sudakshina Das received M.Sc degree in Zoology with Cell Biology as special paper in the year of 1980 from Gauhati University, Guwahati, Assam. She is an Associate Professor of Department of Zoology and the coordinator of D.B.T. sponsored Institutional Level Biotech Hub of D.H.S.K College, Dibrugarh, Assam,

India.

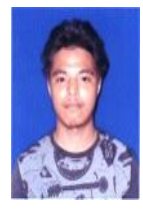

Pradyut Saikia received the B.Sc degree in Biotechnology from North Maharashtra University, Jalgaon, Maharashtra in 2009 and M.Sc degree in Biotechnology from Dibrugarh University, Dibrugarh, Assam in 2011. He is working as a Junior Research Fellow (JRF) at Institutional Level Biotech Hub of D.H.S.K College, Dibrugarh, Assam, India

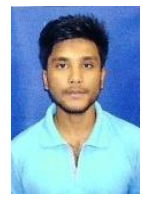

Partha Protim Baruah is a student of Department of Zoology, D.H.S.K College, Dibrugarh, Assam, India. $\mathrm{He}$ is currently pursuing a B.Sc with Zoology as Major subject.

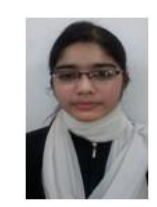

Anuja Chakraborty is a student of Department of Zoology, D.H.S.K College, Dibrugarh, Assam, India. She is currently pursuing a B.Sc with Zoology as Major subject. 